\title{
TTR Gene Mutation
}

National Cancer Institute

\section{Source}

National Cancer Institute. TTR Gene Mutation. NCI Thesaurus. Code C153524.

A change in the nucleotide sequence of the TTR gene. 